\title{
The balance of humus in the degraded heavy clay-loam chernozem under the influence of chicken manure and composts based on it
}

\author{
SkryInyk Ye. ${ }^{1}$, Hetmanenko V. ${ }^{2}$, Kutova A. ${ }^{3}$, Tovstyi Yu. ${ }^{4}$ \\ National Scientific Center «Institute for Soil Science and Agrochemistry Research named after O.N. \\ Sokolovsky» \\ 4 Chaikovska Str., Kharkiv, 61024, Ukraine \\ e-mail: hnu459@gmail.com \\ ORCID: ${ }^{1} 0000-0002-8642-8547,{ }^{2} 0000-0001-9021-3373,{ }^{3} 0000-0003-2680-566 X,{ }^{4} 0000-0002-8206-6112$
}

Goal. To determine the effect of manure and composts on its basis upon the balance of humus in the degraded chernozem. Methods. Field - to determine the effect of organic fertilizers on the humus state of degraded chernozem, laboratory-analytical - to determine the composition of soil samples, calculation - to calculate the balance of humus, mathematical-statistical - to assess the reliability of the data. Results. In the field experiment, they studied the effect and the after-effect of poultry manure and composts on its basis upon the balance of humus in the degraded heavy clay-loam chernozem. It was established that the effect and the after-effect of compost based on chicken manure contributed to the increase of humus content on $8 \%$ and $6 \%$, respectively, as compared to control. It is proved that for 3 years of researches in the $0-20 \mathrm{~cm}$ layer of degraded chernozem they achieved a positive humus balance. The results of calculation of the balance of humus in the degraded chernozem under the influence of chicken manure and compost had shown that the largest negative balance of humus in soil was in the control without fertilizer $-0.24 \mathrm{t} / \mathrm{ha}$. The positive balance of humus $0.8 \mathrm{t} / \mathrm{ha}$ in the degraded chernozem was formed under the influence of chicken manure and compost. The direct influence of the after-effect of manure and composts on the balance of humus in the degraded chernozem was not fixed. Conclusions. For 3 years of researches, they reached a positive balance of humus in the degraded chernozem. The highest accumulation of humus was fixed under the influence of compost (manure + straw) - $0.19 \mathrm{t} / \mathrm{ha}$, the lowest - under the influence of compost (manure + skins) -0.10 t/ha. Accumulation of humus after the application of organic fertilizers was mainly due to the receipt of organic substances together with fertilizers. Greater influence of compost on the balance of humus in comparison with the dung can be explained by the increase of humification of the organic matter of the compost.

Key words: organic matter, organic fertilizers, corn, straw, sunflower husks.

DOI: https://doi.org/10.31073/agrovisnyk202004-03

The humus content is one of the main parameters of fertility, which directly affects the properties of the soil. Change in stocks of humus in the up or down affects groundwater regimes and yield of crops. The accumulation of humus in the soil, primarily depends on the flow ratio of organic matter and its loss due to mineralization. The predominance of the mineralization of organic matter proceeds leads to the destruction of the food chain and changes in environmental operating conditions of the environment. Therefore, planetary preservation of humus has value because it is one of the most important parts of a continuous food chain between different life forms [1, 2].

The main reasons for the decline in humus content, primarily related to a decrease in flow of fresh organic matter to the soil as a result of the alienation of a large part of the biomass harvest and sharp reduction in the use of traditional organic fertilizers. The problem is complicated humus reduction soil quality deterioration of farming in times of economic instability and lack of control over the biological and biochemical processes in the soil [3].

Experts estimate that 120 years of intensive use of soil humus loss reached Ukraine, compared to virgin counterparts in the areas of: $22 \%$ forest steppe, steppe $19.5 \%, 19 \%$ in woodland. According to SI "Institute for Soil Protection" Ukraine $3.6 \mathrm{ml}$. hectares of arable land (4.3\%) is characterized by low humus content [4]. The main routes compensation humus in the soil are: the use of all types of organic fertilizers, green manure, crop of non-tradables, the inclusion of crop rotation legumes and legume-grass mixtures. Intensive use of soil without making sufficient quantities of organic fertilizers, observed recently in Ukraine, humus reduction leads to degradation and reduced soil fertility $[1,5,6]$.

To cover the loss of humus and ensuring a balanced balance its most arable soils requires annual application of organic fertilizer [7, 8]. On average for 2000 - 2014's. In Ukraine contributed less than $1 \mathrm{t} / \mathrm{ha}$ of organic fertilizer on the background of intensification of agriculture cannot cover the loss of humus in the soil [8]. This reduction is due to organic fertilizers, especially a decrease in the number of cattle (cattle) and livestock decline as the sector of the economy because of low economic efficiency. 
One promising avenue leveling loss of humus is rational scientific and reasonable use of local raw materials (animal waste, municipal, industrial, bottom sediments, peat) with their pre-treatment (composting) in which increased their reclamation properties [9-11].

On the background decrease in cattle and poultry farming development in Ukraine should pay attention to the possibility of using litter as the primary sources of organic matter to the soil. The use of litter as organic fertilizer agrophysical improves soil properties, structural-aggregate composition and water treatment processes enhances tumor humic substances. Litter contains about the same amount easy- and soluble components that can not only provide plant available nutrients, but also to maintain and accumulate organic matter in the soil. The systematic introduction of poultry waste as organic fertilizer of humus content increases by an average of $0.35 \%$, depending on soil and climatic conditions [13].

A shortage of high-quality organic fertilizer, the problem of preserving and improving soil fertility is closely linked with more extensive use of organic fertilizers in all possible forms (manure, litter, compost, green manure, straw, etc.) [14].

The purpose of research is determining the effect of litter and compost based on the balance of humus in podzolic chernozem.

Materials and methods of research. Field research conducted on the experimental field of GO RF "Hrakivske" NSC "ISSAR named after Sokolovsky" on podzolic chernozem from 2015 to 2017 years.

The experiment is conducted as follows: 1 - without fertilizer (control); 2 - litter; 3 - compost (litter + straw); 4 - compost (litter + husk). Closing and conducting field experiments performed by the method B.A. Dospekhov [15]. The area sown areas $-59 \mathrm{~m}^{2}$ accounting area $-48 \mathrm{~m}^{2}$. Placing areas random, repetition quadruple.

As the use of organic fertilizers, compost and litter produced on its base with the addition of fillers moisture absorbing (sunflower husk and wheat straw) in a volume ratio of $80 \%$ litter and $20 \%$ filler. Composting spent outdoors with forced aeration by mixing modern equipment (Aeromaster 130). Composting period of 3 months. Dose of compost and litter - $10 \mathrm{t} / \mathrm{ha}$ in terms of the mass fraction of total nitrogen that meets the recommended doses of litter entering Ukraine. Organic fertilizers are made annually in new areas (in May, 2015, 2016, 2017) before planting corn and laying evenly distributing hand shovel. At all sites annually grown corn, root remnants of which earned to the ground.

Soil samples were taken from depths of 0-10, 10-20 cm in late August 2015, 2016 and 2017, after the harvest. Preparation of the samples was performed by ISO 11464 ISO: 2001 [16].

Determination of total carbon performed in the laboratory of organic fertilizer and humus NSC "ISSAR named after Sokolovsky" by Turina for ISO 4289: 2004 [17]. The mass of root remains determined annually for each registration site and transferred on per 1 hectare.

Humus balance calculation made by the method [18].

Calculating the amount of humus formed from the root residues of corn silage, performed by the formula [18]:

\section{$\Gamma \mathrm{k} 1=\mathrm{y} \cdot \mathrm{Kp} \cdot \mathrm{K} \Gamma$}

where $\Gamma_{\mathrm{k} 1}-$ amount of humus formed from the root remnants, $t /$ ha; $\mathrm{Y}-$ crop corn silage, $t / h a ; K_{p}-$ coefficient accumulation of root crop residues on corn silage, 0,21 [18]; $K_{\ulcorner}$- coefficient of root residues humification corn silage, 1.5 [18].

Of organic fertilizers ensures the supply of organic matter to the soil, part of which is directly involved in humus formed. Number of humus formed by making compost and litter on its basis is calculated by the formula [18]:

\section{$\Gamma_{\mathrm{K} 2}=$ Дорг $, \mathrm{KI} \cdot \mathrm{K} \Gamma \cdot 0,25$}

where $\Gamma_{\mathrm{k} 2}$ - the number of newly formed humus organic fertilizers $t /$ ha; $\boldsymbol{Z}_{\mathrm{opr}}$ - made dose of organic fertilizer, $10 \mathrm{t} / \mathrm{ha}$; $\mathrm{K}_{\mathrm{n}}$ - coefficient of litter and compost based on litter to 1,2 and 1,4 respectively [19]; $K_{\mathrm{r}}-$ humification coefficient of organic fertilizers, 0.33 [18]; 0.25 - coefficient of litter dry matter [18].

The expenditure of the humus balance includes mineralization of soil organic matter in view of the technological features of growing corn for silage, physical and chemical properties of podzolic chernozem and climatic conditions. Determining the number of humus, mineralized by growing corn for silage conducted by the formula [18]:

\section{$\mathrm{B}=[\cdot \mathrm{H} \cdot \mathrm{A} \cdot \mathrm{KM} \cdot \mathrm{K} \sigma$}

where, $\mathrm{B}$ - mineralization of humus, t/ha; $\Gamma$ - humus content in the soil, $\% ; \mathrm{H}-$ the depth of topsoil, $20 \mathrm{~cm}$; Д - density assembly podzolic chernozem, $1.1 \mathrm{~g} / \mathrm{cm}^{3}$ [18]; $K_{\mathrm{M}}$ - rate of mineralization of humus, 0,0125 [18]; $\mathrm{K}_{5}-$ the relative index of biological productivity of 1.065 [18].

The calculation of the balance of humus in podzolic chernozem made with regard to the formation of humus by humification introduced litter, compost, corn root residues and mineralization of humus. Loss of humus due to erosion in the calculation did not account for. Calculations made by the formula [20]:

$$
\mathrm{B} r=\Gamma \mathrm{r} 1+\Gamma \mathrm{k} 2-\mathrm{B}
$$

where $\bar{S}_{\Gamma}-$ balance of humus, $t /$ ha; $\Gamma_{\mathrm{k} 1}-$ amount of humus formed from the root remnants, $t / \mathrm{ha} ; \Gamma_{\mathrm{k} 2}-$ the number of newly formed humus organic fertilizers $t / h a ; B-$ mineralization of humus $t / h a$. 
The results are statistically processed using the software package in AgCStat MO Excel [21].

Results and discussion. The content of organic matter - a major fertility parameter that directly affects groundwater regimes and yield of crops. To cover the loss of humus and ensuring a balanced balance its most arable soils requires annual application of organic fertilizers in quantities of 8-15 t/ha, taking into account the climate zone. The systematic application of organic fertilizer from poultry waste of $10 \mathrm{t} / \mathrm{ha}$ for 3 years has increased the humus content in an average of $8 \%$ and 6 under the influence of their actions and aftereffects, respectively. This can be explained by the fact that the organic fertilizer from poultry waste with significant agrophysical soil properties, structural-aggregate composition and water treatment, increasing the formation of humic substances.

Low content of total carbon (1.7\%) identified under control without fertilizer. This litter performance contributed to an increase of total carbon in the soil by $5 \%$, and making compost (litter + straw) and compost (litter + husk) on 8 and 12\% compared to controls (Fig. 1).

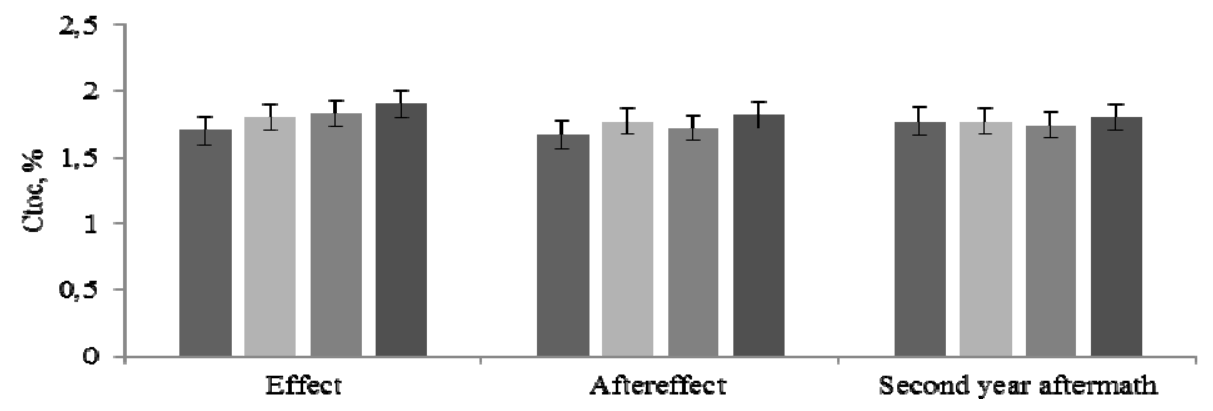

Fig. 1. Content $C_{\text {toc }}$ in podzolic chernozem under litter and compost: - control; - - litter; compost (litter + straw); - compost (litter + husk)

Significant impact action compost from litter can explain about the same number of easily-soluble components, and that can not only provide plant available nutrients, but also to maintain and accumulate organic matter in the soil [4].

Aftereffects litter and compost had a less significant impact on $\mathrm{C}_{\text {toc }}$ content in the soil compared to the action. The lowest content $C_{\text {toc }}$ defined under control without fertilization and is (1.67\%), which was almost unchanged compared with the effect of organic fertilizers (Fig. 1). The greatest influence on the content $\mathrm{C}_{\text {toc }}$ defined in aftereffect compost (litter + husk), which is (1.82\%). Aftereffects compost from litter contributed to an increase $C_{\text {toc }}$ content, by transforming soluble fertilizer components made in the first year.

It should be noted aftereffect second year of litter and compost did not affect the content $\mathrm{C}_{\text {toc }}$. On the fertilized plots content $\mathrm{C}_{\text {toc }}$ set at control within $1.74-1.80 \%$ (Fig. 1). That in turn points to the small prolonged action litter and compost content $\mathrm{C}_{\text {toc }}$.

Changes humus content in the soil depends on two mutually opposing processes - humification (tumor humus) and mineralization of organic matter. The result is their intensity accumulation or loss of humus. In order to set the direction and intensity of these changes, using the balance method which takes into account Article receipt and disposition of soil organic matter. The main items of income, followed by organic matter humification is the root-crop remains and introduced organic fertilizers. The main reasons are the loss of humus mineralization and soil erosion. Number of humus that can be formed with a root-crop residue depends on the yield of the main product, qualitative and quantitative characteristics of culture. Calculation humus balance reflects the impact of farming on the total carbon content in the soil, how well equipped the soil organic matter and helps to compare the efficacy of different fertilizing systems.

The results of calculating the balance of humus in podzolic chernozem under the influence of litter and compost showed the largest negative balance of humus in the soil defined under control without fertilization $(-0.24) \mathrm{t} /$ ha (Fig. 2). Scarce balance of humus formed under control due to lack of revenues due to organic matter and root residues removed from the field of non-tradables entire crop. Instead, a positive balance of humus in podzolic chernozem installed under the influence of litter and compost. The accumulation of humus due, primarily, to the arrival of fresh soil organic matter and turning it into parts humus podzolic chernozem. 


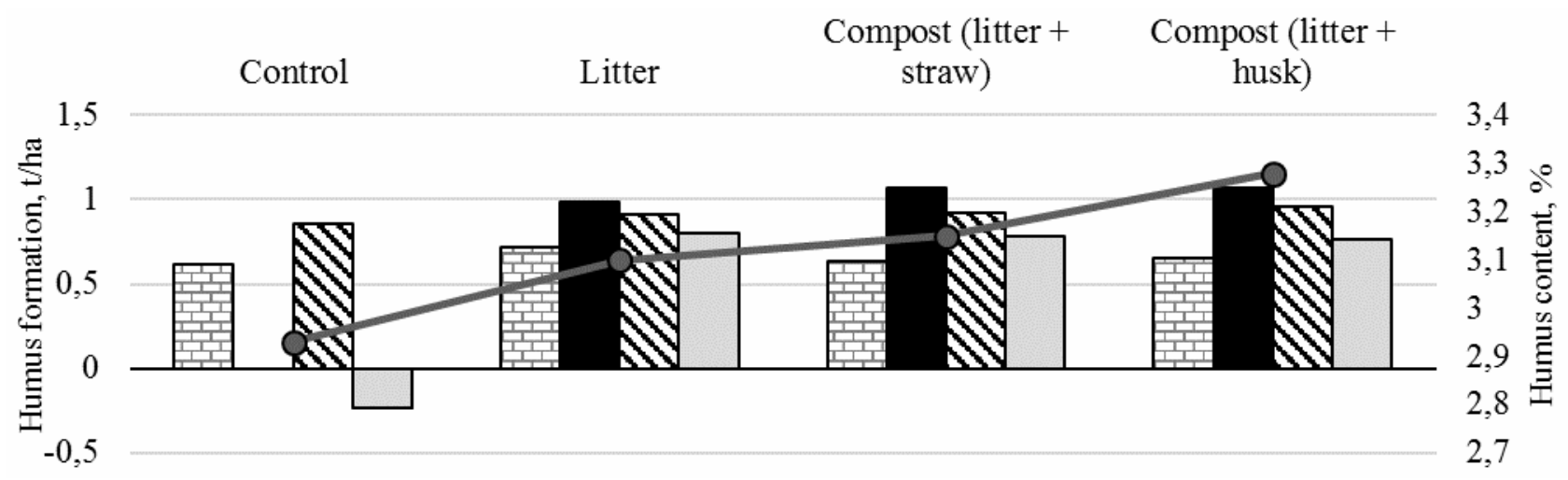

Fig. 2. The balance of humus in podzolic chernozem under effect litter and compost: - humus

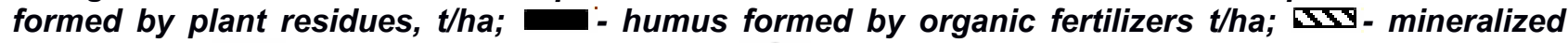
humus, $t / h a ; ~-~ t h e ~ b a l a n c e$ of humus, t/ha; $-0-$ - humus content, $\%$

Undefined significant effect on the balance between performance humus litter, compost (litter + straw) and compost (litter + husk), which is associated with a similar degree of humification of organic compost component. It is also worth noting that most of humus by plowing root residues formed on option with the introduction of the litter. Weight root residues increased by the largest yield of maize silage in comparison with other variants of the experiment.

Aftereffects litter and compost based on it had no significant effect on the balance of humus in podzolic chernozem (Fig. 3).

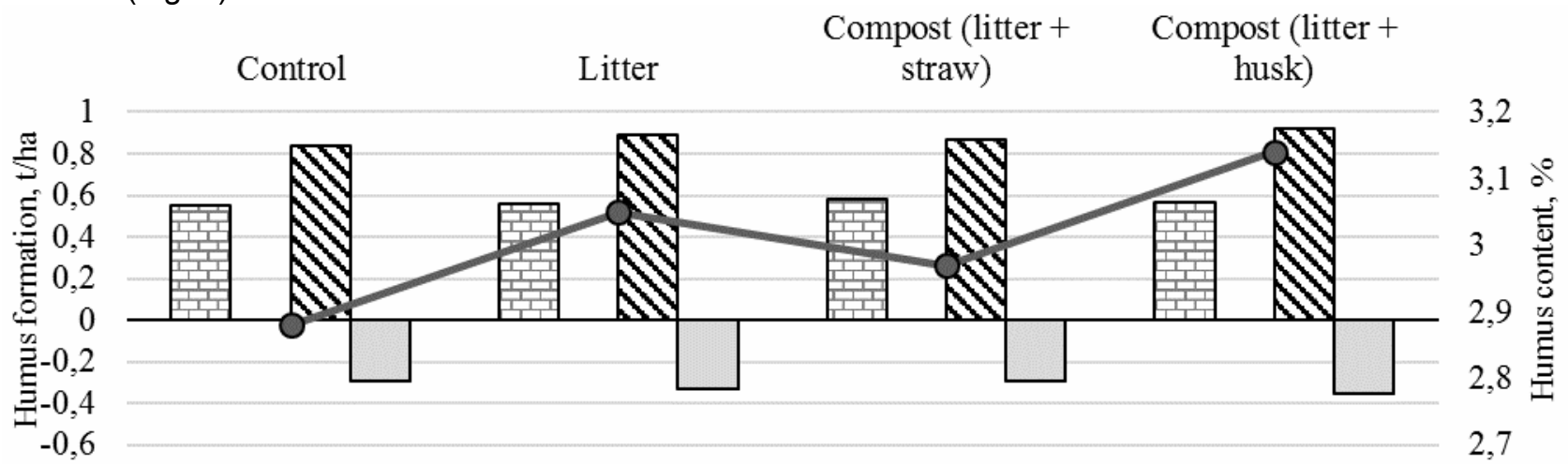

Fig. 3. The balance of humus in podzolic chernozem under the influence of second year aftermath litter and compost:- humus formed by plant residues, $t$ /ha; - humus formed by organic fertilizers t/ha; Wv - mineralized humus, t/ha; $\square$ - the balance of humus, t/ha; $-0-$ - humus content, \%

Also, the tendency to increased loss of humus under the influence aftereffect of litter and compost (litter + husk). The balance of humus under the influence of the aftereffect of compost (litter + straw) remained at the controls $(-0.29) \mathrm{t} / \mathrm{ha}$.

Not defined beneficial effects aftereffect second year of litter and compost humus in the balance podzolic chernozem, which may explain the absence of additional revenues of organic matter to the soil by organic fertilizers and depositing the same number of root residues to the soil (Fig. 4).

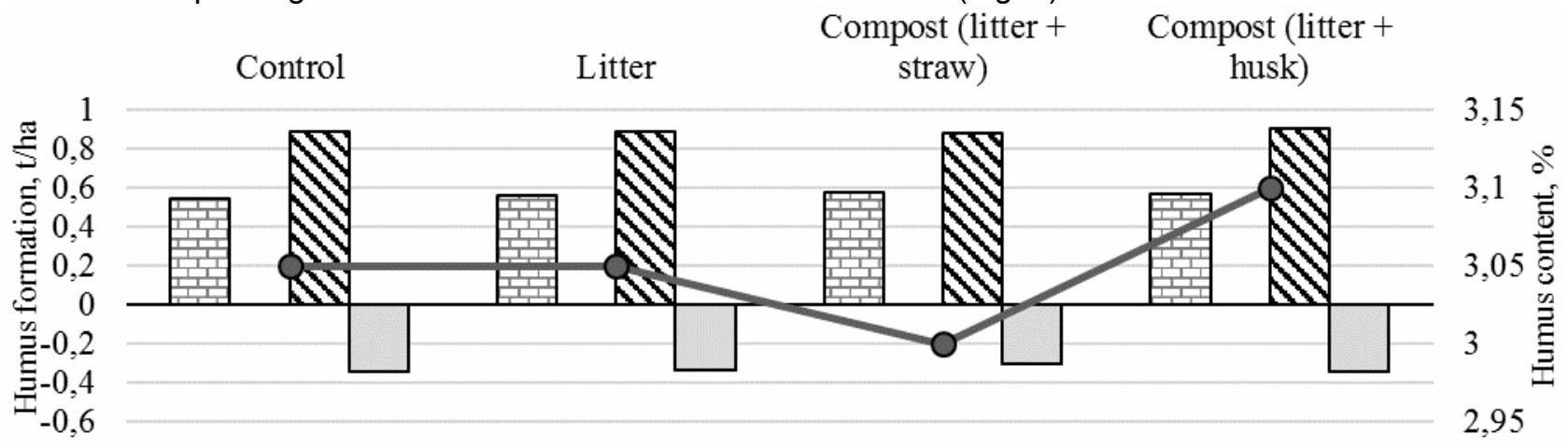

Fig. 4. The balance of humus in podzolic chernozem under the influence aftereffectsecond, the litter and compost: - humus formed by plant residues, $t$ /ha; - humus formed by organic fertilizers t/ha; Wv - mineralized humus, t/ha; $\square$ - the balance of humus, $t / h a ;-0-$ - humus content, $\%$ 
litter Analysis settlement formation of humus in podzolic chernozem gives reason to believe that plowing plant residues and organic fertilizers, humus compensate losses as a result of mineralization. Studies indicate that over the years the experiment humus balance under control without fertilization was scarce, and the loss of humus were $(-0.88)$ t/ha due to mineralization. In exchange for making litter, compost (litter + straw) and compost (litter + husk) managed to achieve a positive balance of humus formation at $0.13 ; 0.19$; $0.10 \mathrm{t} / \mathrm{ha}$, respectively. Improving the balance of humus on organic fertilizers was mainly due to receipt of organic matter along with fertilizers.

\section{Conclusions}

In total over three years of research in podzolic chernozem managed to achieve a positive balance of humus formation. The greatest accumulation of humus determined under the influence of compost (litter + straw) 0.19 t/ha, and least influenced compost (litter + husk) 0.10 t/ha. The accumulation of humus on organic fertilizers was mainly due to receipt of organic matter along with fertilizers.

\section{References}

1. Gotzea, P., Rucknagela, J., Jacobsb, A., Marlanderb, B., Kochb, \& H., Bettina (eds.) (2015). Sugar beet rotation effects on soil organic matter and calculatedhumus balance in Central Germany. European Journal of Agronomy, 76, 198-207. doi: 10.1016/j.eja.2015.12.004.

2. Okorkov, V., Okorkova, L., \& Fenova, O. (2016). Changes in the content of humus in gray forest soils under long-term fertilization. Russian agricultural sciences, 42(2), 149-154. doi: $10.3103 / \mathrm{S} 1068367416020105$.

3. Orlova, N., \& Orlova, O. (2012). Sravnitelnaya otsenka sovremennogo sostoyaniya i funktsionirovanie gumusa tselinnykh i okulturennykh dernovo-podzolistykh pochvakh. [Comparative evaluation of the current state and functioning of humus tsilinnih and cultivated sod-podzolic soils]. Pochvy Rossii: sovremennoe sostoyanie, perspektivy Izuchenie $i$ ispolzovanie [Soils Russia: Current State, Prospects Learning and Using]. (pp. 324-331). Moscow, Russian. [In Russian].

4. Baliuk, S., Medvediev, V., \& Tarariko, O. (eds.) (2010). Pro stan rodiuchosti gruntiv Ukrainy: natsionalna dopovid [The state of soil fertility Ukraine: National Report]. [In Ukrainian].

5. Plotnikov, A., Gorbunov, M., \& Utkin, A. (2016). Estimated criterion of agricultural lands' damage when soil humus is decreased. Bulletin of Kurgan State Agrarian Academy, 113, 60-63.

6. Cerbari, V., \& Leah, C. (2016). Green manure-only possibility to save Moldova's arable soils from degradation. Scientific Papers. Series Agronomy, 59(2), 155-158.

7. Erhart, E., Schmid, H., Hartl, W., \& Hülsbergen, K. J. (2016). Humus, nitrogen and energy balances, and greenhouse gas emissions in a long-term field experiment with compost compared with mineral fertilisation. Soil Research, 54(2), 254-263. doi: 10.1071/SR15127.

8. Kasper, M., Freyer, B., Hülsbergen, K. J., Schmid, H., \& Friedel, J. K. (2015). Humus balances of different farm production systems in main production areas in Austria. Journal of Plant Nutrition and Soil Science, 178(1), 25-34. doi: 10.1002/jpln.201400111.

9. Spychalski, W., Grzebisz, W., Diatta, J., \& Kostarev, D. (2018). Humus stock degradation and its impact on phosphorus forms in arable soils-a case of the Ukrainian Forest-Steppe Zone. Chemical Speciation \& Bioavailability, 30(1), 33-46. doi: 10.1080/09542299.2018.1457985.

10. Novikov, A. (2018). Ordinary chernozems humus by fertilization and cultivated agricultural crops efficiency. Scientific Journal of Russian RDI of Melioration Problems, 2, 131-143.

11. Juknevičienè, E., Danilčenko, H., Jarienè, E., \& Fritz, J. (2019). The effect of horn-manure preparation on enzymes activity and nutrient contents in soil as well as great pumpkin yield. Open Agriculture, 4(1), 452459. doi: $10.1515 /$ opag-2019-0044.

12. Prokopchuk, I., Prokopchuk, S., Hospodarenko, H., \& Trus, A. (2018). Humus content in a podzolized chernozem after a long-term application of fertilizers in a field crop rotation. Agronomy Research, 16(3), 728-736. doi: 10.15159/ar.18.080.

13. Temirov, U., Namazov, S., Usanbaev, N., Sultonov, B., \& Reymov, A. (2018). Organic-mineral Fertilizer Based on litter e and Phosphorite from Central Kyzylkum. Chemical Science International Journal, 24. 1-7. doi: $10.9734 / C S J I / 2018 / 43452$.

14. Erhart, E., Schmid, H., Hartl, W., \& Hülsbergen, K. J. (2016). Humus, nitrogen and energy balances, and greenhouse gas emissions in a long-term field experiment with compost compared with mineral fertilisation. Soil Research, 54(2), 254-263. doi: 10.1071/SR15127.

15. Dospekhov, B. A. (1985). Metodika polevogo opyta [Methods of field experience]. Moscow: Agropromizdat. [In Russian].

16. DSTU ISO. 11464:2001. Yakist gruntu. Poperednie obrobliannia zrazkiv dlia fizyko-khimichnoho analizu. (2003). [Pre-treatment of samples for physical and chemical analysis]. Chynnyi z 2009-10-01, Kyiv: Derzhspozhyvstandart. [In Ukrainian].

17. DSTU 4289: 2004. Yakist gruntu. Metody vyznachennia orhanichnoi rechovyny. (2005). [Methods for determination of organic matter]. Chynnyi z 2005-07-01, Kyiv: Derzhspozhyvstandart. [In Ukrainian].

18. Hrekov, V. A., \& Datsko, L. V. (2008). Rozrakhunok balansu humusu [Calculate the balance of humus]. Kerivnytstvo ukrainskoho khliboroba [Guide Ukrainian farmer]. (pp. 202-203). Kyiv. [In Ukrainian]. 
19. Kravchenko, V. A. (2007). Metodicheskie ukazaniya i spravochnyy material dlya sostavleniya kursovogo proekta (raboty) po sisteme primeneniya udobreniy $v$ sevooborotakh. [Guidance and reference for drafting course project (work) on the system of fertilizers in crop rotations]. Yeletsk: Eletskii State University. I. A. Bunin. [In Russian].

20. Chesnyak, G. Ya., Batsula, A. A. \& Derevyanko, R.G. (1987). Parametry gumusnogo sostoyaniya pochv. Obespechenie bezdefitsitnogo balansa gumusa $v$ pochve [Settings humus soil. Providing a balanced balance of humus in the soil]. Kyiv: Urozhay. [In Ukrainian].

21. Gonchar-Zaykin, P. P., \& Chertov, V. G. (2003). Ratsionalnoe prirodopolzovanie i selskokhozyaystvennoe proizvodstvo $v$ yuzhnykh regionakh Rossiyskoy Federatsii [Environmental management and agricultural production in the southern regions of the Russian Federation]. Moscow: Modern notebooks. [In Russian]. 